Acta vet. scand. $1984,25,333-345$.

From the National Veterinary Institute, Oslo, the Institute for Energy Technology, Kjeller, and the Department of Chemistry, University of Trondheim, Dragvoll, Norway.

\title{
LEVELS OF TRACE ELEMENTS IN LIVER FROM NOR WEGIAN MOOSE, REINDEER AND RED DEER IN RELATION TO ATMOSPHERIC DEPOSITION
}

By

A. Frøslie, G. Norheim, J. P. Rambæk and E. Steinnes

FRØSLIE, A., G. NORHEIM, J. P. RAMBEK and E. STEINNES: Levels of trace elements in liver from Norwegian moose, reindeer and red deer in relation to atmospheric deposition. Acta vet. scand. 1984, 25, 333-345. - The levels of antimony, arsenic, cadmium, copper, lead, mercury, molybdenum, selenium and zinc were determined in liver of moose, reindeer and red deer from differen localities in Norway. Reindeer had considerably higher levels of mercury, lead and arsenic than moose and red deer. These findings are considered to be related to differences in feeding habits since reindeer on highland plateaus feed mainly on lichens which have been shown to accumulate trace elements. The levels of arsenic, and to some extent also selenium and cadmium, in moose and reindeer liver showed a north-south gradient closely related to the regional distribution of these elements in the forest moss. As regards lead, a north-south gradient and a relationship to moss levels, were found in moose liver only. It therefore seems that atmospheric deposition of the elements mercury, lead, arsenic, cadmium and selenium contribute to the body burden of these elements in cervides in Norway. There was no evidence of these elements accumulating to toxic levels.

wild-life; cervides; antimony; arsenic; cadmium; copper; lead; mercury; molybdenum; selenium; zinc; air pollution; environmental pollution.

Air pollution of local or distant origin may contribute significantly to the load of heavy metals in natural terrestrial ecosystems. Deposition of metals in the surface soils may induce elevated levels in the plants (Tjell et al. 1979). Elevated levels of metals in the plants may in turn increase the load in herbivorous animals. Plants my also be contaminated by direct deposition from the air (Tjell et al. 1979). 
In Norway, atmospheric deposition of lead, cadmium and some other relatively volatile trace elements is about a tenfold higher in the southernmost part of the country as compared with the more northerly regions (Hanssen et al. 1980). This fallout is mainly the result of long-distance atmospheric transport from central Europe. About the same regional distribution of these elements has been found in surface soils (Allen \& Steinnes 1980) and coniferous forest ecosystems (Solberg \& Steinnes 1983). A similar geographic distribution has also been found in the levels of these trace elements in liver of lambs grazing natural pastures (Frøslie et al. 1985 to be published).

The present study was carried out to ascertain whether similar regional distributions existed in the heavy metal burden borne by the cervides: moose, reindeer and red deer.

\section{MATERIALS AND METHODS}

Depending on the natural distribution of the different species, liver samples of moose (Alces alces), reindeer (Rangifer tarandus) and red deer (Cervus elaphus) were collected from 13 localities throughout the country (Fig. 1). Samples from moose, wild reindeer and red deer were collected during the hunting season in the autumn of 1978. Samples from semi-domestic reindeer were collected at slaughter in the same autumn. Samples were also collected from reindeer at Karasjok (in northern Norway) at the end of the winter pasture season in 1979. Five samples were selected from each locality and submitied for analysis in the frozen state.

Levels of antimony, arsenic, mercury, molybdenum and selenium in liver samples were determined by radiochemical neutron activation analysis (Steinnes 1975). Copper and zinc were determined by flame atomic absorption spectrometry (AAS), and cadmium and lead by graphite furnace AAS after wet digestion. The results are expressed in $\mathrm{ppm}(\mu \mathrm{g} / \mathrm{g})$ or $\mathrm{ppb}(\mu \mathrm{g} / \mathrm{kg})$ on a wet weight basis.

\section{RESULTS AND DISCUSSION}

Analytical results are presented in Tables 1 and 2, and are also illustrated in Figs. 2, 3 and 4. Mercury levels were considerably higher in reindeer than in moose and red deer (Fig. 2). Among the reindeer, those from Karasjok winter pasture (point 12, Fig. 


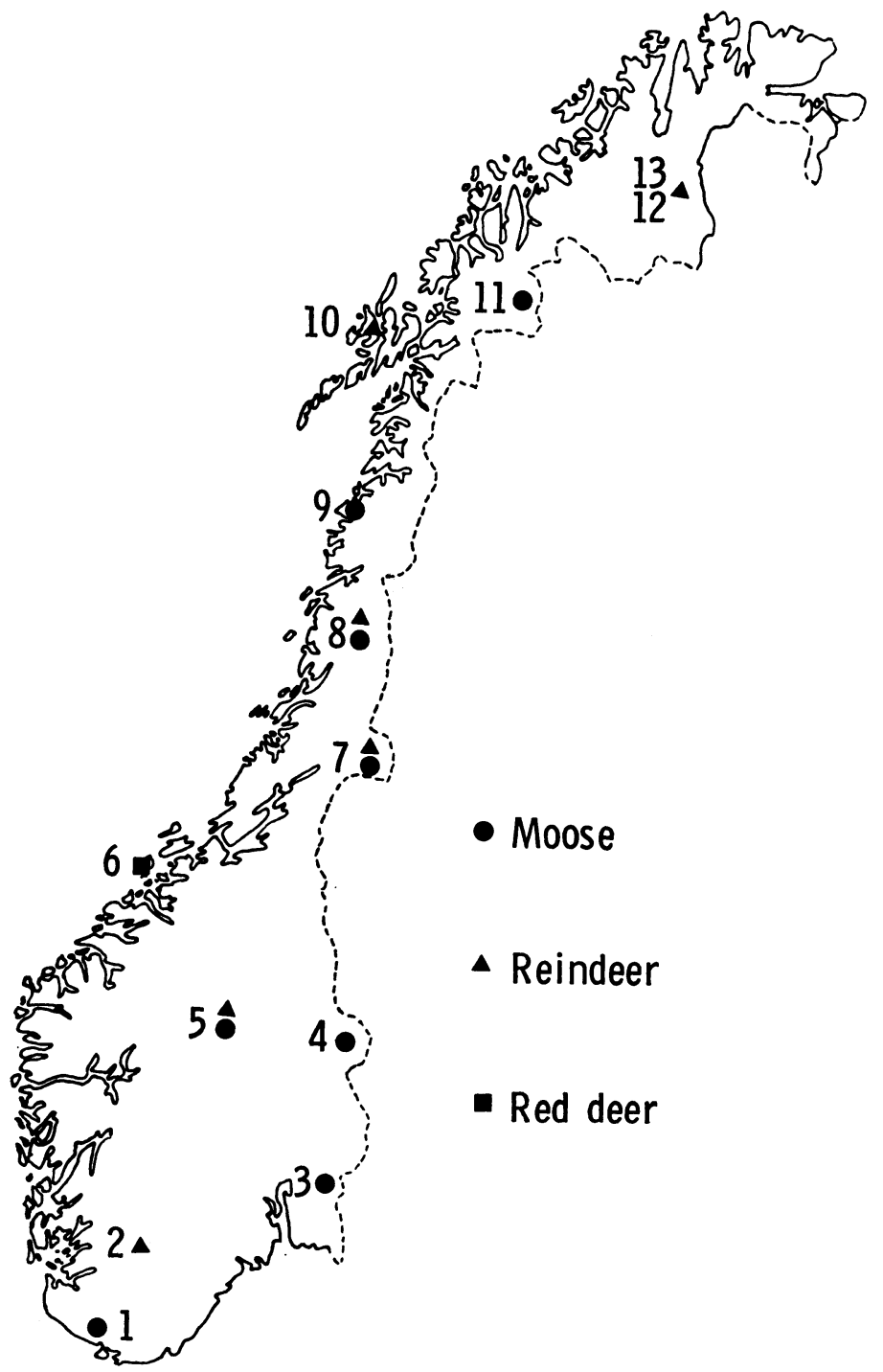

Fig u re 1. Localization of sampling areas.

Moose: $\quad$ Flekkefjord (1), Rømskog (3), Trysil (4), Dovre (5), Lierne (7), Hattfjelldal (8), Melфy (9), Målselv (11).

Reindeer: Setesdalsheiene (2), Dovre (5), Lierne (7), Hattfjelldal (8), Sortland (10), Karasjok winter pasture (12), Karasjok summer pasture (13).

Red deer: Smøla (6). 







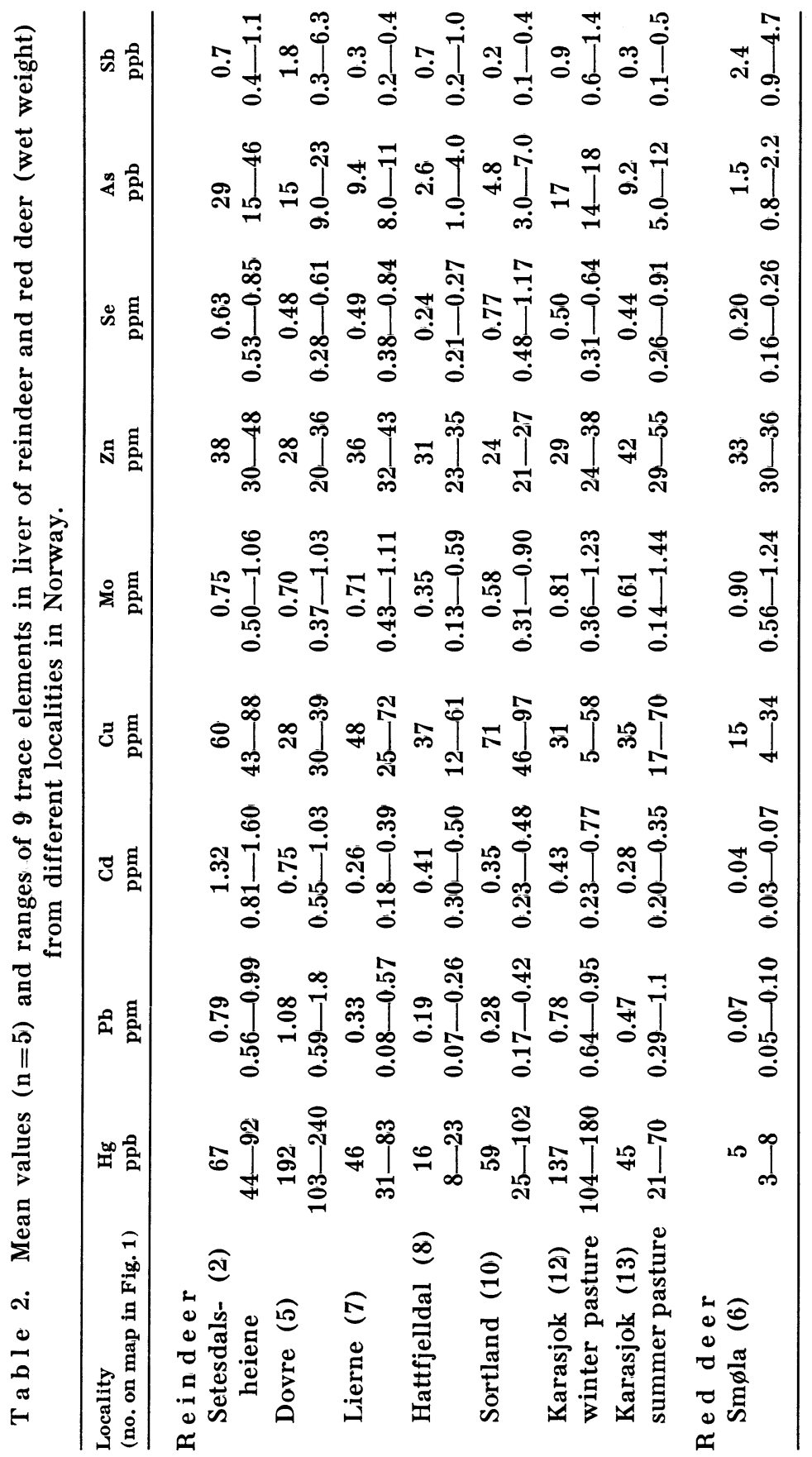



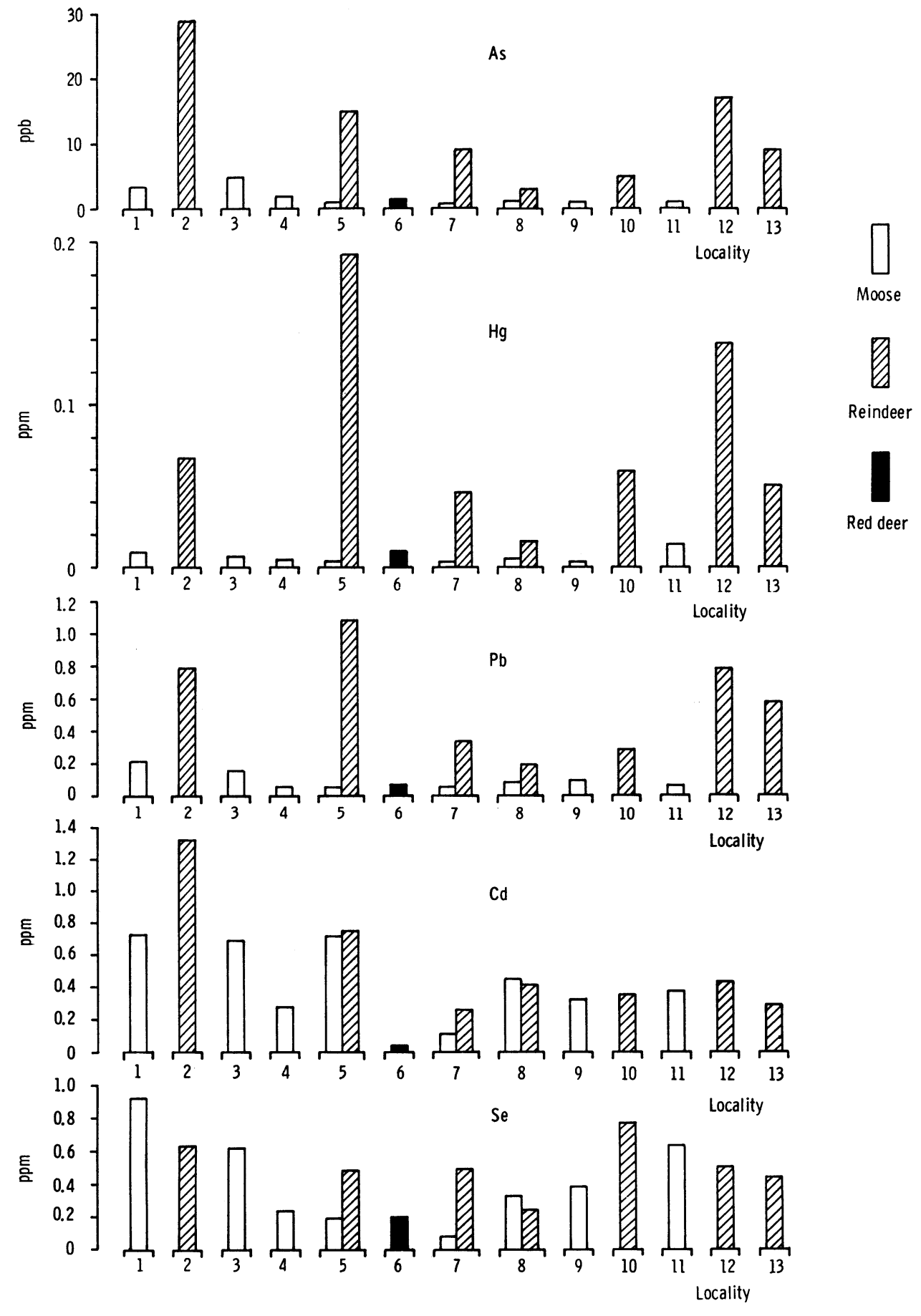

F ig u r e 2. Comparison of levels of arsenic, mercury, lead, cadmium and selenium in liver of moose, reindeer and red deer from 13 localities as illustrated in Fig. 1. 

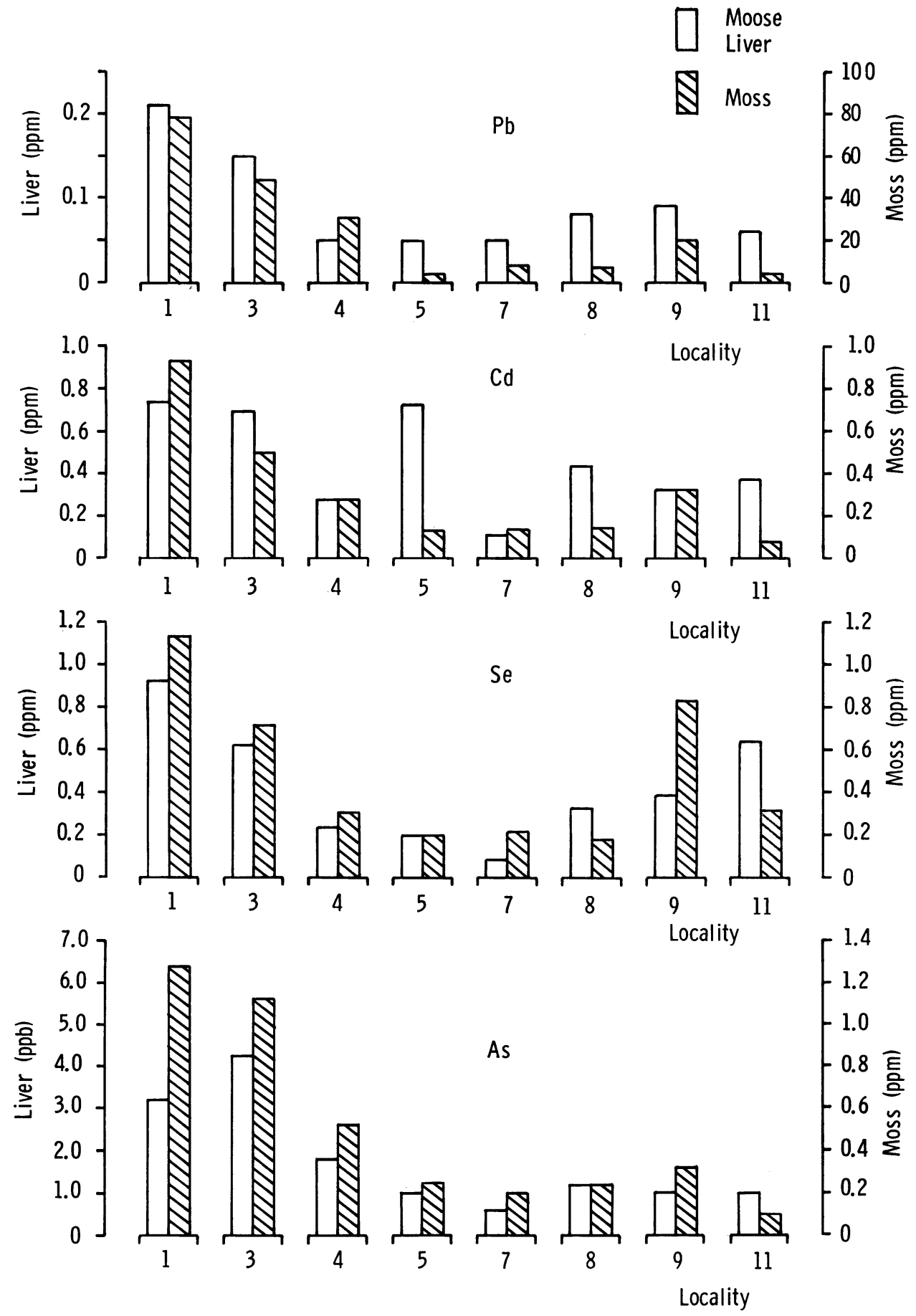

Figu re 3. Comparison of levels of lead, cadmium, selenium, and arsenic in moose liver and forest moss from 8 different localities as illustrated in Fig. 1. 


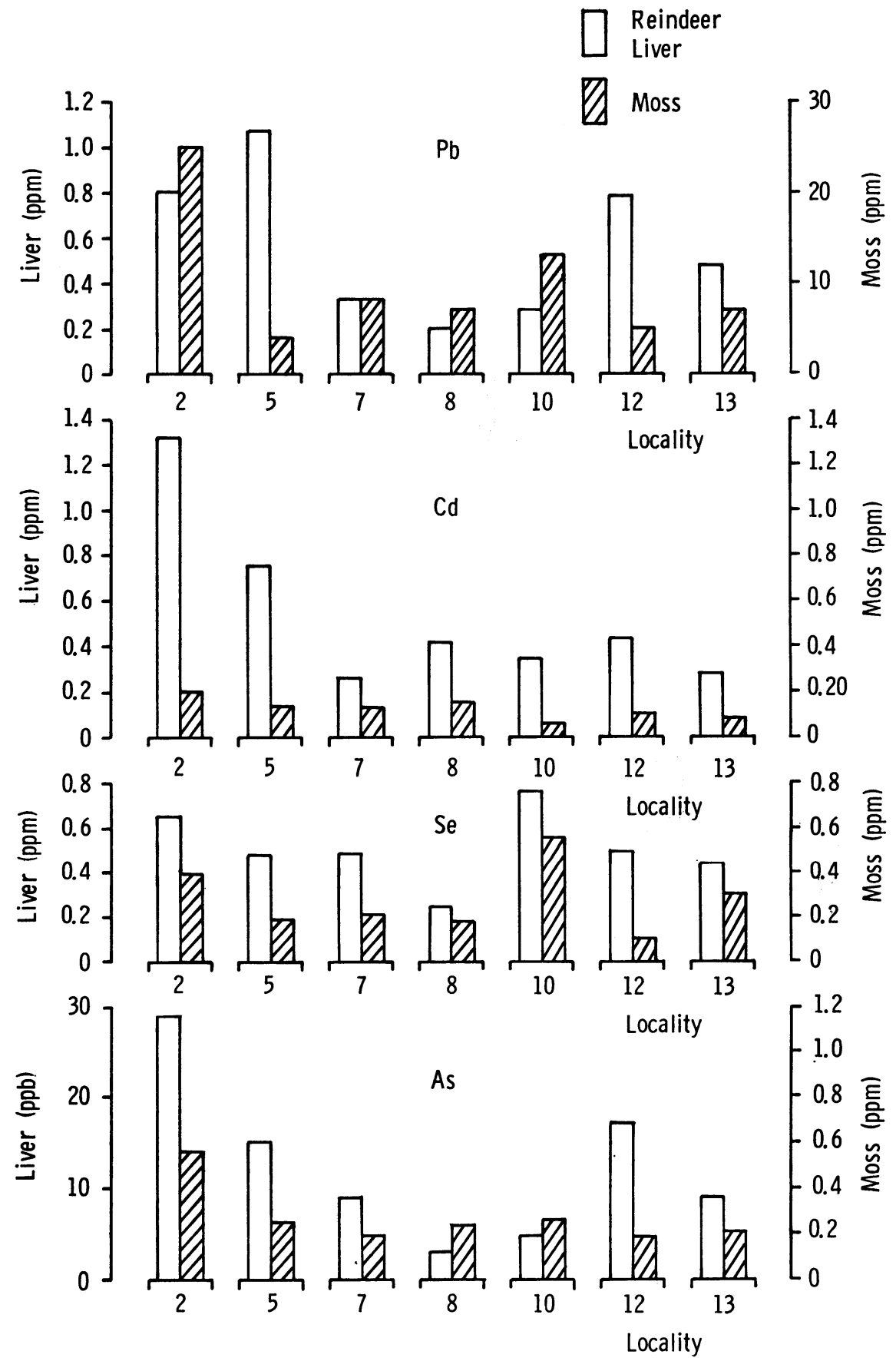

F i g u r e 4. Comparison of levels of lead, cadmium, selenium, and arsenic in reindeer liver and forest moss from 7 different localities as illustrated in Fig. 1. 
1), and especially those from Dovre (5) were the ones with the heaviest contaminant burden. These findings correspond well with the proportion of lichens in the feed. Reindeer on mountain plateaus feed mainly on lichens, while those living in the deciduous woods feed, as do moose and red deer, on grasses, herbaceous plants and foliage. Moose also feed on coniferous trees. Reindeer from Karasjok are nomadic, i.e. they graze grasses and herbaceous plants at the coast in the summer, while they are moved to the inland planteau in Finnmark in the winter, where their diet consists mainly of lichens. It has been shown that lichens are able to accumulate mercury from the air (Steinnes \& Krog 1977). Background levels of mercury in lichens are from 0.05 to $0.2 \mathrm{ppm}$ (Steinnes 1977) while levels in grasses, herbaceous plants and foliage are probably close to $0.001 \mathrm{ppm}$, the same order of magnitude as found in Norwegian cereals (Låg \& Steinnes 1978). One may therefore conclude that atmospheric deposition most probably contributes significantly to the mercury load in cervides, especially in reindeer on lichen pastures.

Similar differences between reindeer and moose were also seen as regards the levels of arsenic and lead, reindeer from Setesdalsheiene (2), Dovre (5) and Karasjok (12,13) being the most heavily loaded. These findings may also be related to differences in nutrition as discussed above.

With the exception of mercury, the atmospheric deposition pattern in Norway of the elements in question has been mapped by extensive studies of samples of forest moss (Hylocomium splendens) collected at more than 500 sites all over the country, coupled with analysis of precipitation at a limited number of places (Rambæk \& Steinnes 1980, Hanssen et al. 1980). Deposition figures for lead, cadmium, arsenic and selenium are substantially higher in the southern and south-western parts of Norway than in central and northern Norway. North-south gradients are not so pronounced for molybdenum and zinc, and are even less obvious for copper.

There was scarcely any sign of a north-south gradient in the levels of lead in reindeer liver, and there was no significant correlation between levels $i$ reindeer liver and those in moss from different localities. It thus seems that differences in feeding habits in reindeer overwhelm regional differences in atmospheric deposition of lead. 
There was a clear tendency for levels of lead and arsenic in moose liver to show a north-south gradient, the same being to some extent true for selenium and cadmium in moose liver and arsenic, selenium and cadmium in reindeer liver. Correlation coefficients for levels in moose and reindeer liver versus levels in moss were as follows:

$\begin{array}{lcc} & \text { Moose liver } / \text { moss } & \text { Reindeer liver } / \text { moss } \\ \mathrm{Pb} & \mathrm{r}=0.92^{\star \star} & \mathrm{r}=0.02^{\mathrm{ns}} \\ \mathrm{Cd} & \mathrm{r}=0.56^{\mathrm{ns}} & \mathrm{r}=0.83^{\star} \\ \mathrm{Se} & \mathrm{r}=0.77^{\star} & \mathrm{r}=0.79^{\star} \\ \mathrm{As} & \mathrm{r}=0.93^{\star \star \star} & \mathrm{r}=0.76^{\star}\end{array}$

The difference between moose and reindeer as regards liver concentrations of lead and arsenic and the very high correlation between liver levels in moose and levels in moss, both indicate that atmospheric deposition contributes significantly to the body burden of these two elements in cervides.

Concerning cadmium, the correlation between levels in liver and moss is weak and scarcely significant. Cadmium is, however, an element that accumulates in the body with age. This is also the situation in moose, accumulation taking place especially in the kidneys, but also in the liver (Mattsson et al. 1981, Holt et al. 1983). The relationship between the accumulation of cadmium and the age of the animals could, however, not be ascertained from the present material due to the small number of samples from each area. Possible north-south gradients may therefore have been confounded to some degree by age differences.

Selenium deficiency diseases are well recognised in domestic ruminants in Norway, especially in the inland districts (Frøslie et al. 1980). The occurrence of these diseases is related to the nutrition of the animals, and corresponds well with the regional differences in liver selenium in sheep. A positive correlation has also been found between selenium levels in lambs' liver and moss from different localities of the country (Fr $\not s l i e$ et al. 1985). The positive correlations between selenium levels in moose and reindeer liver and moss found in the present investigation fit well with these findings and lead to the conclusion that atmospheric deposition may make a benificial contribution to the supply of selenium to herbivorous animals on natural pastures. As far as the authors are aware, selenium deficiency diseases have not been diagnosed in cervides in Norway. Nor do the selenium levels 
found in the present investigation indicate selenium deficiency in general, though there were a few samples of moose liver from Dovre (5) and Lierne (7) with selenium levels below the assumed deficiency level of $0.05-0.1 \mathrm{ppm}$. Selenium deficiency is well known in sheep in these areas. Kurkela \& Kääntee (1979) reported very high levels of selenium in reindeer from Finnish Lapland with mean values in skeletal muscles of $0.70 \mathrm{ppm}$ wet weight. Such high levels were not found in reindeer meat from Karasjok, the mean in this case being $0.16 \pm 0.02 \mathrm{ppm}$ selenium (Fr $\phi$ slie unpublished results). The corresponding mean value of $0.45 \pm 0.11 \mathrm{ppm}$ found in liver from these reindeer, corresponds well with the levels determined in the present investigation.

The levels of zinc found in the present investigation showed small regional differences. Liver levels seemed to be slightly higher in reindeer than in moose.

The levels of antimony were generally very low and showed no significant regional differences. Nor were regional differences observed in the levels of copper and molybdenum. Copper and molybdenum are metabolic antagonists in ruminants, and it seems that the situation in cervides is as in sheep (Frøslie et al. $1985)$, e.g. that atmospheric deposition of these elements is of minor significance for the actual body load.

Red deer are mainly located in the western parts of Norway, a circumstance which makes a reliable study of regional differences in this species hardly a feasible proposition. Moreover, the 5 samples examined originated from the island of Smøla which has typical peat soils, poor in several trace elements ( $L a ̊ g ~ 1975)$. The low levels of some of the trace elements found in the present samples of red deer liver, may be related to the quality of this particular type of soil.

Recently, levels of lead, cadmium, copper, zinc and selenium were determined in liver samples from 11 reindeer shot on Spitsbergen in April 1984 (Reimers \& Schreiner, pers. comm.). The following mean concentrations were found: $1.40 \mathrm{ppm} \mathrm{Pb}, 1.05$ ppm Cd, 86 ppm Cu, 41 ppm $Z n$ and 0.84 ppm Se. These levels are comparable with the highest levels recorded in reindeer in Norway.

With the exception of the generally higher levels of selenium and mercury found in reindeer liver, the levels of trace elements found in this study were of the same order of magnitude as those found in lambs' liver (Fr $\phi$ slie et al. 1985). There is no evidence 
of accumulation of elements to toxic levels, nor does there seem to be any general need to recommend restrictions in the human consumption of liver from these animals. A possible reservation to this general statement could, however, perhaps be taken with regard to the relatively high levels of cadmium.

It may be concluded from the present investigation that atmospheric deposition of mercury, lead, arsenic, cadmium and selenium contribute to the body burden of these elements in cervides in Norway, and that feeding habits of the animals influence the extent of this contribution.

\section{REFERENGES}

Allen, R. O. \& E. Steinnes: Contribution from long-range atmospheric transport to the heavy metal pollution of surface soils. In: Ecological impact of acid precipitation. Eds. D. Drabløs \& A. Tollan. SNSF project, Oslo-Ås 1980, p. 102-103.

Frøslie, A., G. Norheim, J. P. Rambæk \& E. Steinnes: Heavy metals in lamb liver: Contribution from atmospheric fallout. Bull. Environm. Contam. Toxicol. 1985, 34 (to be published).

Hanssen, J. E., J. P. Rambæk, A. Semb \& E. Steinnes: Atmospheric deposition of trace elements in Norway. In: Ecological impact of acid precipitation. Eds. D. Drabløs \& A. Tollan. SNSF project, Oslo-Ås 1980, p. 116-117.

Holt, G., A. Frøslie \& G. Norheim: Forekomst av kadmium hos ville drø tyggere i Norge. (Cadmium in wild ruminants in Norway). Norsk Vet.-Tidsskr. 1983, 95, 341-342.

Kurkela, P. \& E. Kääntee: The selenium content of skeletal (gluteal) muscle of Finnish reindeer and cattle. Zbl. Vet. Med. B 1979, 26, $169-173$.

Låg, J.: Noen særtrekk ved jordsmonnet på Smøla og i lignende områder langs den norske vestkysten. (Characteristics of soils on Smøla and similar areas along the western coast of Norway). Ny Jord 1975, No. 3, 65-75.

$L a ̊ g, J . \& E$. Steinnes: Contents of some trace elements in barley and wheat grown in Norway. Meld. Norg. LandbrHøgsk. 1978, 57, No. 10, $11 \mathrm{pp}$.

Mattsson, P., L. Albanus \& A. Frank: Kadmium och vissa andra metaller i lever og njure från älg. Underlag för kostrekommendation. (Cadmium and some other elements in liver and kidney from moose (Alces alces).) Vår Föda 1981, 33, 335-345.

Rambæk, J.P. \& E. Steinnes: Atmospheric deposition of heavy metals studied by analysis of moss samples using neutron activation analysis and atomic absorption spectrometry. In: Nuclear methods in environmental and energy research (Conf-800433). US Department of Energy 1980, p. 175-180. 
Solberg, W. \& E. Steinnes: Heavy metal contamination of terrestrial ecosystems from long-distance atmospheric transport. Proc. Conf. Heavy Metals in the Environment, Heidelberg 1983, Vol. I, p. $170-173$.

Steinnes, E.: A two-group separation scheme for the determination of eleven trace elements in biological material by neutron activation analysis. Anal. Chim. Acta 1975, 78, 307-315.

Steinnes, E.: Atmospheric deposition of trace elements in Norway studied by means of moss analysis. Report KR-154, Institutt for atomenergi, Kjeller, Norway 1977, 29 pp.

Steinnes, E. \& H. Krog: Mercury, arsenic and selenium fall-out from an industrial complex studied by means of lichen transplants. Oikos 1977, 38, 160-164.

Tjell, J. C., M. F. Hovmand \& H. Mosbæk: Atmospheric lead pollution of grass grown in a background area in Denmark. Nature 1979, $280,425-426$.

\section{SAMMENDRAG}

Luftforurensninger som mulige kilder til akkumulering av sporelementer hos norske hjortedyr.

Lever av elg, rein og hjort fra 12 forskjellige områder av landet er analysert for innhold av elementene antimon, arsen, bly, kadmium, kobber, kvikks $\varnothing l v$, molybden, selen og sink. Rein hadde et betydelig høyere innhold av bly, kvikks $\varnothing l v$ og arsen enn de andre artene, noe som kan skyldes beiting på lav som er kjent for å kunne akkumulere sporelementer. Resultatene av analysene er videre sammenholdt med tidligere data for innhold av sporelementer $i$ humus fra de samme områdene. Det ble funnet korrelasjon mellom nivåene av bly, arsen, selen, og i noen grad kadmium, i humus og elg- og reinlever. Et unntak er bly i reinlever, hvor beiteforholdene synes å ha større betydning enn forskjeller i nedfall. Det var tydelige nord-s $\phi r$ gradienter for disse elementene hos elg og rein. Både forskjellen mellom rein og de andre artene og de påviste nord-s $\varnothing \mathbf{r}$ gradientene tyder på at atmosfærisk nedfall er av betydning for akkumuleringen av elementene arsen, bly, kadmium, kvikks $\varnothing l v$ og selen hos norske hjortedyr. Det er i denne unders $\emptyset$ kelsen ikke påvist nivåer av de aktuelle elementer som kan ha toksikologisk betydning. Innholdet av kadmium i lever kan ha en viss næringsmiddelhygienisk betydning

(Received May 16, 1984).

Reprints may be requested from: A. Frøslie, the National Veterinary Institute, P. O. Box 8156 Dep, 0033 Oslo 1, Norway. 